\title{
An Antitrust Assessment of the Google Book Search Settlement ${ }^{1}$
}

\author{
Mark A. Lemley, Durie Tangri LLP²
}

The Google Book Search settlement has prompted a flurry of attention from commentators, including a number of respected scholars who have worried that the settlement makes Google an "orphan works monopoly." ${ }^{3}$ In this paper I evaluate these claims and find them generally unpersuasive. The Google Book Search settlement expands, rather than diminishes, access to books of all sorts, and that is particularly true of orphan works. ${ }^{4}$

\section{Background}

Let's review the state of the world before Google decided to digitize a large fraction of the world's books. A small number of books were in print, and these books were available for purchase from publishers. Another fraction were in the public domain, either because they were published before 1923, or because they were published in the 20 s, 30s, or 40 s and were not renewed, as required by copyright law at that time. In between were a large class of works that were not available for purchase from publishers, but not free for the taking either. As I explain below, access to these works was limited to those who could obtain them from libraries; indeed, many were only available in major research institutions.

1 (c) 2009 Mark A. Lemley.

2 The reader should be aware that I represent and have been compensated by Google in the case and settlement I analyze here, and that my wife is employed by Google, so I am not an unbiased observer. Thanks to Susan Creighton, Alex MacGillivray, Derek Slater, and Dana Wagner for comments and contributions to this draft.

3 See, e.g., James Grimmelmann, How to Fix the Google Book Search Settlement, 12:10 J. Internet L. 1 (April 2009); Randal C. Picker, The Google Book Search Settlement: A New Orphan-Works Monopoly?, http://ssrn.com/abstract=1387582; Pamela Samuelson, The Dead Souls of the Google Booksearch Settlement, 52 Comm. ACM (July 2009).

4 I do not in this analysis assess any possible antitrust issues that arise from horizontal agreements among authors or publishers pursuant to the settlement. 
In theory, someone who wishes to republish an out-of-print work can simply contact the copyright owner and seek permission. One would expect book owners to be taking advantage of the online world's ability to match up buyers and sellers cheaply enough that it makes sense to make the books available online. In practice, however, matters are more complex. As I'll discuss further below, the current costs to a potential licensee of both finding the rightsholder and clearing the rights may outweigh the potential profit from re-publishing any given work. As a result, millions of out-of-print books remain unavailable to the world as a practical matter, except to those who happened across a copy in a particular library or a used bookstore.

If approved by the court, the Google Book Search settlement will change that. The settlement will permit Google to digitize most books published in the U.S. Members of the public will have access to electronic copies of previously unavailable works: It will be possible to search the content of the books for free, and to preview full pages from out-of-print books for free, allowing members of the public to find the books and the information they need. People who decide they want a book for themselves will be able to buy a digital version that they can read online. Libraries will be given licenses to provide free, complete access to out-of-print books at terminals in their buildings. And institutions will be able to buy subscriptions to vast catalogs of works. The public gets access to works that have, as a practical matter, been unavailable for years or decades and have never been searchable; authors and publishers get revenue from works that had long since stopped generating any. The result is clearly beneficial to all concerned.

Why, then, are some scholars complaining about the settlement? Critics point out that some books will be "orphans." While people do not always define this term in the same way, they generally mean books whose rightsholders are "virtually impossible to locate." ${ }^{5}$ Under the agreement, Google will

\footnotetext{
${ }^{5}$ See Samuelson, supra note 3.
} 
be able to make available the "orphaned" books that were previously unavailable. The agreement is non-exclusive all the way around, yet critics worry that Google will have a "monopoly" over these works. They claim that these works make up the vast majority of all works, and that Google will gain an unfair advantage over competing services. The implied claim is that no one else will be in a position to provide a competing database of the truly orphan works.

There are three problems with this analysis. First, critics overstate the breadth of the "orphan works problem" for books, and they overlook the ways that the settlement will help others license most out-of-print books. Second, the Google orphan works "monopoly" is not a monopoly at all. It is not illegal to be the first to introduce a new innovation. If it were, we wouldn't have made much progress as a society. Finally, even if the result of the settlement were a monopoly, monopoly alone is not bad or illegal per se. One provider of these books is better than zero, and Google is not violating the antitrust laws because it is not engaged in "monopolization." I consider each point in turn.

\section{Untangling Book Copyrights}

Most in-copyright but out-of-print books were published after $1963 .{ }^{6}$ The problem that has kept this part of our cultural heritage inaccessible isn't principally that we don't know how to find the authors or publishers. Rather, the biggest problem in most cases will be that the digital rights are unclear. Until recently, for example, most copyright assignments did not specify what to do about digital rights, leading courts to conclude that one party may own the rights to physically reprint a work and an entirely different party the rights to electronic reproductions. Ownership in older works is also complicated by

6 The US Copyright Office conducted a study in 1961 that found that less than $10 \%$ of books had complied with the copyright renewal requirements, which means the vast majority of older books subject to the renewal right in fact are not "orphans" but rather are owned by the public. But to make use of those books, the public must be aware of their copyright status. One unheralded but very important part of the Google Book Search project has been the efforts of Google and others to scan, clean up, and then make available the Copyright Office records in digital formats for anyone to easily download for free, so that the world can find out for certain which of the $90+\%$ of these older books in fact are free for the public to use. 
the statutory provision for termination of transfers, which permits authors or their heirs to get back the copyright in works they assigned to others between 35 and 40 years after publication. ${ }^{7}$ If the author retained the copyright, but died, the laws of succession may mean that many different people jointly control the rights to a work.

Thus, today a re-publisher faces not only the search costs of finding the rightsholder, but also a tangle of uncertain copyrights and a high cost of making a mistake in clearing the rights, which can subject the publisher to statutory damages that far exceed any actual loss to the copyright owner. It generally just isn't worth it to unscramble the claims, particularly because these books have limited -- or at least uncertain -- market potential. And so the books sit there, inaccessible and unread.

The Google Book Search settlement will help clear a path through this legal thicket and make it easier for anyone to license out-of-print works. The settlement creates a non-profit, collective rights organization called the Book Rights Registry, which will collect revenue on rightsholders' behalves and then distribute it to them. The Registry is also required to create and make available information about which books have been claimed under the settlement, and by whom. ${ }^{8}$ In other words, once a book is claimed, everyone will be able to find out the identified owner and how to contact that person. In addition, rightsholders can allow the Registry to license works on their behalf, reducing transaction costs for other digital book initiatives even further. ${ }^{9}$

As time goes by, more and more out-of-print books are likely to be claimed, particularly books that are most commercially valuable. After all, since rightsholders can make money through Book Search or other services licensed by the Registry, they have a good reason to come forward. If a rightsholder has not yet come forward, the Registry will hold collected revenue on his or her behalf for 5 years (or

717 U.S.C. $\S 203$.

${ }^{8}$ Settlement $\S 6.6(\mathrm{~d})$.

${ }^{9}$ Settlement $\S 6.2(\mathrm{~b})(\mathrm{iii})$. 
until the rightsholder comes forward and claims the money owed to them). Meanwhile, the settlement puts millions of dollars towards an extensive notice program, and the Registry will actively attempt to locate rightsholders who have yet to claim their works under the settlement. ${ }^{10}$

So rather than giving Google any "monopoly" over most-out-of-print books, the settlement actually lowers the barriers and risks for any follow-on competitor that wants to license out-of-print books. Unlike Google, which faced hundreds of thousands of copyright claimants, Google's potential competitors can deal with the Registry for most works of interest. The Registry can always do a better deal with competitors, and the entire agreement is non-exclusive. For example, suppose at the time the Registry goes effective there are ten million registered works. The Registry could do a deal that day with Amazon for all ten million books on better terms than Google gets. Or a year later Amazon could propose to "cream skim" and do a deal for the one million best-selling works (saving itself the costs of scanning millions of unprofitable books). Amazon get can a better deal from the Registry for those "cream skimming" books than Google gets. Alternatively, Amazon can do deals directly with the rightsholders themselves on whatever terms they choose.

\section{A Monopoly of Knowledge?}

Having said that, the orphan works problem exists for a minority of books. ${ }^{11}$ Does Google have a monopoly over those true "orphans"?

\footnotetext{
${ }^{10}$ Settlement $\S 6.1(\mathrm{c})$. The settlement provides that $\$ 34.5$ million go towards the Registry's initial startup and cover the costs of its operations, including locating rightsholders. Later it will be able to use unclaimed funds to do so.

${ }^{11}$ Denise Covey's study was unable to locate the publishers of $21 \%$ of all books currently under copyright. Denise Troll Covey, Acquiring Copyright Permission to Digitize and Provide Open Access to Books (2005). This number may overstate the actual number of orphans. As discussed above, the settlement will for the first time put millions of dollars towards finding rightsholders and create clear monetary incentives for them to come forward, and one can expect that this will lead most books to be claimed. Critics of the settlement have assumed that the majority of books are truly orphaned, see e.g., Brewster Kahle, "A Google Book Grab," http://www.washingtonpost.com/wp-
} 
First, it is strange to talk about a "monopoly" over an ill-defined set of books. Nobody knows which books are actually orphaned. Furthermore, the term "monopoly" is usually applied with respect to an economic market for a good and its substitutes. Orphan works seem unlikely to constitute a separate market, because many if not all will contain comparable content to non-orphaned books. And by definition, the orphaned works are the ones that no one has been willing to keep in print or even keep track of, so it seems unlikely that there is much demand for those works that cannot be met at least in part by an alternative work.

It is also a bit odd to talk of Google having a monopoly over works that are already available at libraries and used bookstores throughout the country. The argument is that Google Book Search has made those books so much more accessible and useful that it has in fact created an entirely new marketing opportunity. Put another way, these scholars would argue, once orphan works are available online, libraries, used bookstores, and other sources for books and the information they contain simply do not compete with the kind of searchable, downloadable access Google provides. One might well question whether this is true; the Internet (and indeed Google) has facilitated the location of out-ofprint books from used booksellers through services such as Amazon, and more traditional sources will remain an alternative way for people to find books and access information.

But even if it is true, a company does not possess a monopoly as antitrust law understands the term merely because it is the first to enter a market. Monopoly in antitrust law means something different - not just that a company has substantial market share, but that there are barriers to entry that are so significant that as a practical matter no one can enter the market to compete even if the incumbent raises its price.

dyn/content/article/2009/05/18/AR2009051802637.html (saying that 50-70\% are orphaned); Samuelson, supra (saying 70\% are out-of-print, and "most" are orphans). While no one knows for sure exactly how many books will remain truly orphaned, it seems unlikely to be anything that large. 
The question, then, is what stands in the way of Yahoo! or Microsoft or Amazon or the Open Content Alliance doing the same thing Google has done? One argument is that rescanning the books is simply too expensive. But that argument is unpersuasive. Antitrust law is normally quite unsympathetic to claims that the plaintiff shouldn't have to build its own plant in order to compete with one the defendant just built. The only exception to this rule - the essential facilities doctrine - is both extraordinarily rare in application and much-criticized by commentators and indeed Supreme Court Justices. ${ }^{12}$ Google has spent a lot of money to scan the books in its database, but not so much money that a motivated competitor couldn't duplicate that effort. ${ }^{13}$ While in some sense that effort would be "wasted," we have lots of circumstances in which companies construct duplicate or overlapping databases - think Lexis and Westlaw, for example. It is a starting premise of antitrust law that the value of competition is worth the cost of duplication. And not all of that work would be duplication. A competitor could choose to scan different books from different sources in addition to or instead of the ones Google has catalogued. They could use different scanning technologies, or better or worse resolution, or put the resulting data in a different format. There is plenty of room for competition here.

A more interesting argument is that no one can duplicate Google's effort because anyone who did so would face a lawsuit similar to the one filed against Google. Even assuming that this is the case, it is not clear that the fact that Yahoo! or Microsoft would have to face the same risk Google did should change the analysis. Much of the criticism of the Google Book Search settlement seems to stem from a

12 See, e.g., Verizon Communications v. Law Offices of Curtis v. Trinko, 540 U.S. 398 (2004) (denying that the Supreme Court has ever adopted an essential facilities doctrine); Philip Areeda, Essential Facilities: An Epithet in Need of Limiting Principles, 58 Antitrust L.J. 841 (1989).

${ }^{13}$ In fact, the Open Content Alliance (OCA) has already said that they plan to scan in-copyright but outof-print books and offer them to users through the interlibrary loan system. See: http://openlibrary.org/details/oca test 004/leaf10. Brewster Kahle, who leads the OCA, has remarked that digitizing books and making them accessible online is "not that expensive." See Kahle, supra. 
belief that Google's use of the books was a fair use and so not an act of copyright infringement. ${ }^{14}$ For what it's worth, I agree. There is nothing to prevent Yahoo! or Microsoft from litigating the same case to judgment, winning, and then being able to digitize the works and show snippets without paying the price Google has paid. Nothing would prevent them from attempting to negotiate the same or similar terms in a settlement. Of course, doing so is risky, because the statutory damages rules (mistakenly, in my view) ${ }^{15}$ threaten not just compensation but dire punishment if the defendant gets it wrong. But Google faced the same risk; it is more than a little odd to say that Google violates the antitrust laws because it has a monopoly that arises solely from the fact that it is more willing to take chances than its competitors.

If anything, the settlement reduces the risks of others trying to do exactly what Google did. As discussed above, follow-on competitors can work with the Registry to license the claimed books. For books that remain unclaimed indefinitely, follow-on competitors will not know for sure whether the book is truly "orphaned" and whether the rightsholder will ever come forward. However, they will know that the rightsholder has chosen not to come forward despite the financial incentives for them to do so (e.g., money made through Google and other Registry-licensed services). Follow-on competitors will be able to evaluate the risk of copyright damages for digitization and use of the book in light of this fact. By contrast, Google pursued its digitization without the benefit of this information.

14 See, e.g., Samuelson, supra; Peter S. Menell, Knowledge Accessibility and Preservation Policy for the Digital Age, 44 Hous. L. Rev. 1013 (2007) (arguing that Google Book Search is fair use; the article was written before the settlement). But see Grimmelmann, supra: "some commentators dislike the settlement because they think that we'd be even better off if the case proceeded to trial and judgment. They'd been hoping that Google would have established that its scanning and searching features were fair uses. If Google had prevailed on the fair use issue, it would have opened the book search business to anyone, free from legal taint. What's more, it would have given us a powerful, portable fair use principle that could do a lot of other good in this digital age. While a definitive finding of fair use would have been better than the settlement, that's not the choice on the table.... [T] here's no guarantee that Google would have won on the fair use issue."

15 Mark A. Lemley, Should a Licensing Market Require Licensing?, 70 L. \& Contemp. Probs. 185 (2007). 


\section{One Is Better Than Zero}

Nevertheless, critics suggest that Google will always be the only provider of the orphan books, and that this "monopoly" will cause a great deal of harm. James Grimmelmann predicts that "Google's extraordinary market power under the settlement will come from its unique lock on orphan works," and a parade of horribles will follow.

For one thing, it is hard to fathom how a license to use old, orphan books will give Google any "extraordinary market power." Out-of-print books as a whole make up a tiny fraction of book sales, and the orphans are likely be the least commercially valuable among them and have the least reader interest. One would not expect the rightsholder of a valuable work to abandon it completely. While some rightsholders probably made a mistake in abandoning their books, and with Google Book Search will come to recognize that fact, those rightsholders are the ones who will join the Registry and so competitors will be able to find and deal with them. The "monopoly" at issue here is, by definition, only over works that no one even bothers to come forward and claim.

Nor is this limited control the sort of monopoly that antitrust law considers actionable. Google might be the only company in the market by virtue of its being the first to enter, but one company providing an important new service is better than no companies doing so. And if the publishers would have won the underlying lawsuit, no companies doing so is just what we would have had. (There was no evidence that the book publishers had any intention of digitizing orphan works and making them available, either individually or collectively.) Antitrust recognizes this; that's why we approve patent pools when the patents in question are in fact necessary to practice the technology. ${ }^{16}$

16 See, e.g., U.S. Department of Justice and Federal Trade Commission, Antitrust Guidelines for the Licensing of Intellectual Property (1995). 
The Google Book Search settlement actually provides more access to orphan works than Google provided while the lawsuit was pending; that additional access would likely not be fair use, and so competitors probably couldn't duplicate it without themselves doing a deal with the publisher. ${ }^{17}$ But that fact is a reason to support rather than to oppose the settlement. The problem that has kept much of our cultural heritage inaccessible isn't principally that we don't know how to find the authors or publishers, it is the tangle of legal rights surrounding those books. Litigation can't solve this problem; even if Google had litigated and won on fair use grounds, it would have provided only indexing and short snippets of orphan works. So in this respect, the settlement provides Google - and the public - more than the law of fair use would. In this case the "one is better than zero" point has particular force: without Google's investment in digitization, and without the settlement, the public would never have had online access to the host of works that have been effectively abandoned by their owners.

The objection, then, must be not that Google shouldn't be allowed to provide a valuable new service, but that others should be able to provide it too. Fair enough. But that's hardly a reason to object to the settlement. Yahoo!, Microsoft or Amazon could come to the same deal with authors and publishers. In fact, in most respects it is far easier for them to do so after the settlement than it was before. The settlement creates a new Registry with the ability to license all the works that are registered with it, and in virtually all circumstances, the settlement actually allows the Registry to license on better terms to Google's competitors. ${ }^{18}$

17 Even this is not clear; there is a plausible argument that duplication of the entirety of an out-of-print work costs the copyright owner nothing and is therefore a fair use.

18 It is not clear whether the Registry will be able to license unclaimed works to a third party unless that party goes through its own settlement process. But the settlement agreement expressly provides that the Registry can grant such licenses. Any restriction results from copyright law or the law of civil procedure, not from the settlement agreement. Even if the settlement doesn't eliminate every barrier to a second entrant who wants to license these works, it makes entry much easier. There is now an entity to negotiate with, and a model for others to use. Moreover, the settlement dramatically reduces the number and likely commercial significance of the unclaimed works, and hence the need for any such 


\section{There Is No Anticompetitive Conduct Here}

Finally, as any antitrust lawyer will tell you, merely possessing a monopoly is not illegal. The Sherman Act prohibits only "monopolization" - the willful acquisition or maintenance of monopoly power by anticompetitive means. The only conduct Google has engaged in is the scanning of millions of books now accessible only in major libraries and the settlement of the resulting lawsuit, and the courts have traditionally shown substantial, even extreme, deference both to innovative activity of this kind and to the settlement of legitimate IP suits. ${ }^{19}$ The settlement here does nothing on its face to restrict competition. True, it has a nondiscrimination provision, which requires that if the Registry licenses a significant portion of unclaimed works to third parties within ten years of the settlement becoming effective, Google is entitled to the same terms as those third parties. ${ }^{20}$ But these sorts of clauses are quite common, and have generally been held legal. ${ }^{21}$ Given that Google faced substantially more risk and incurred substantially higher costs in opening this market than its competitors will face in following in its footsteps, the fact that those competitors can't get a better deal for unregistered works for a limited time doesn't seem unreasonable. Nor is it evidence of an intent to monopolize. Without proof

license. Most, if not all, valuable works are likely to be claimed, reducing the need for a new entrant to seek licenses for those works not included in the Registry. And copyright owners ought to have substantial incentive to enter into such a deal, since reaching Yahoo! or Amazon users who don't use Google would presumably expand their market, and for orphan works any payment is pure profit to the copyright owners.

19 Indeed, courts bend over backwards to defer to settlements even when, unlike this one, they seem clearly anticompetitive. See, e.g., In re Tamoxifen Citrate Antitrust Litig., 466 F.3d 187 (2d Cir. 2006); In re Ciprofloxacin Hydrochloride Antitrust Litig., 544 F.3d 1323 (Fed. Cir. 2008); Asahi Glass Co. v. Pentech Pharms., Inc., 289 F. Supp. 2d 986, 992 (N.D. Ill. 2003) (Posner, J.).

${ }^{20}$ Settlement § 3.8(a).

${ }^{21}$ See, e.g., Blue Cross \& Blue Shield United of Wisconsin v. Marshfield Clinic, 65 F.3d 1406, 1415 ( $7^{\text {th }}$ Cir. 1995) ("Most favored nations clauses are standard devices by which buyers try to bargain for low prices, by getting the seller to agree to treat them as favorably as any of their other customers.... [T] $T$ hat is the sort of the conduct that the antitrust laws seek to encourage."); IIIB Philip Areeda \& Herbert Hovenkamp, Antitrust Law ๆ 768a6, at 159-60 (3d ed. 2008) ("We would never condemn a dominant firm's insistence" on a most-favored nations clause as long as the clause requires only equal rather than preferential treatment). 
of both an intent to take over the market and anticompetitive conduct that helps a company do so, even a monopolist hasn't violated the antitrust laws.

\section{The Perfect and the Good}

A good deal of the opposition scholars have expressed to the settlement seems to be driven by a belief that in the best of all possible worlds, orphan works legislation would remove the barriers to use of out-of-print works for which owners cannot be found. ${ }^{22}$ I agree that well-crafted legislation to expand the use of orphan works would be a good thing. ${ }^{23}$ But there is no reason to assume that orphan works legislation will pass Congress in the near future, or that if it did it would be legislation that expanded the right to use orphan works rather than legislation riddled with restrictions imposed in an effort to reach a legislative compromise. And in any event, there is nothing in the settlement that would prevent or discourage orphan works legislation. If the settlement, and the deals the Registry will doubtless enter into with other tech companies, are not sufficient to open access to orphan works, Congress remains just as free to pass such legislation in the future as it is today. Indeed, the settlement will create a working model of what successful orphan works legislation might look like. To oppose a settlement that will expand access to these works today in the hopes that Congress might choose to do so in the future is to let the theoretical perfect be the enemy of actual good.

I don't intend to suggest that courts or commentators should ignore antitrust issues in analyzing the Google book search settlement. But it seems legally and economically implausible that the settlement will create a Google orphan works monopoly - much less that consumers will be worse off rather than better off as a result of the settlement. The settlement advances, rather than diminishes,

22 See Grimmelman, supra note 3.

23 See Lemley, supra note 15. 
both competition and access to knowledge. Courts shouldn't destroy these benefits in a misguided effort to save them. 